\title{
Data Processing with Unit Record Equipment in Iceland
}

\author{
Óttar Kjartansson \\ (Retired) Manager of Data Processing Department at Skýrr, Iceland \\ ottark@heima.is
}

\begin{abstract}
This paper presents an overview of the usage of unit record equipment and punched cards in Iceland and introduces some of the pioneers. The usage of punched cards as a media in file processing started 1949 and became the dominant machine readable media in Iceland until 1968. After that punched cards were still used as data entry media for a while but went completely out of use in 1982.
\end{abstract}

Keywords: Data processing, unit record, punched card, Iceland.

\section{Hagstofa Íslands}

Hagstofa Íslands (Statistical Bureau of Iceland) initiated the use of 80 column punched cards and unit record equipment in Iceland in the year 1949. The first machinery consisted of tabulating machine of the type IBM 285 (handled numbers only), the associated key punch machines, verifiers, and a card sorter. See Figures 1 and 2. This equipment was primarily used to account for the import and export for Iceland. Skýrr (Skýrsluvélar ríkisins og Reykjavíkurborgar - The Icelandic State and Municipal Data Center) was established three years later by an initiative from Hagstofa Íslands, Rafmagnsveita Reykjavíkur (Reykjavík Electric Power Utility), and the Medical Director of Health of Iceland as was described in an earlier article [3].

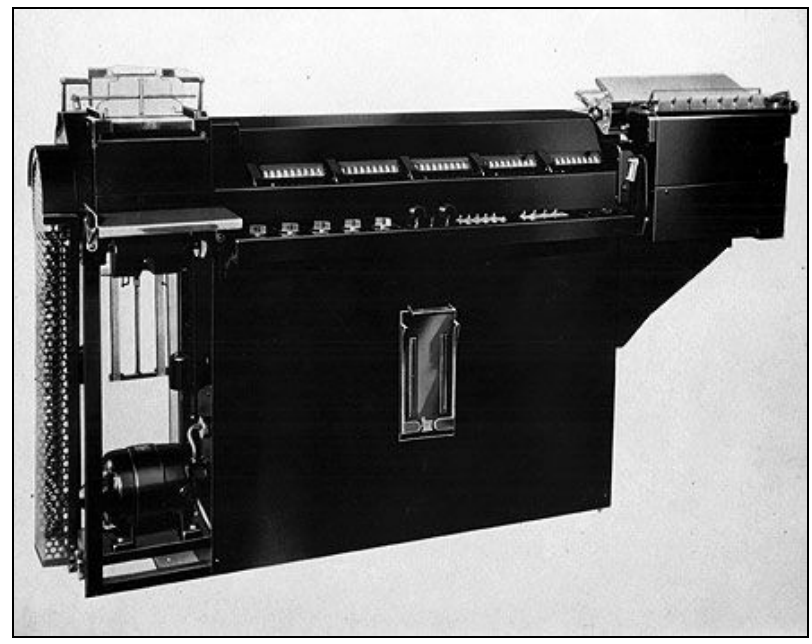

Fig. 1. IBM 285 Electric Accounting Machine at Hagstofa Íslands year 1949 


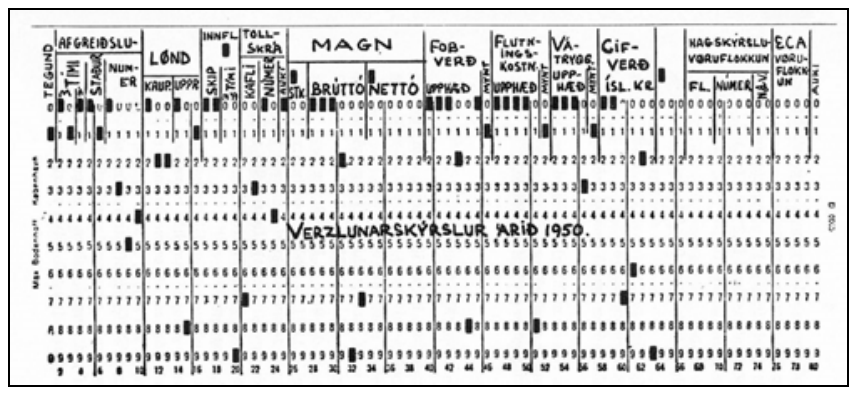

Fig. 2. Early form of the data registration using a punched card. Hagstofa Islands: Import/export account 1950. (Author: Áki Pétursson)

Áki Pétursson (1913-1970) directed the use of this equipment at Hagstofa. He was trained at IBM Denmark and was the first Icelander to obtain such training and he directed Skýrr for the first eight years. Viggo Troels-Smith of IBM Denmark closed the first order for IBM punched card equipment for Iceland - the Hagstofa, in the year 1947. Later Viggo Troels-Smith became the director of IBM Denmark. An agreement was made in the year 1948 with Ottó A. Michelsen (1920-2000) to undertake the maintenance of IBM machines in Iceland. He became sales agent for IBM and later the director of IBM World Trade Company office in Iceland [1].

\section{Rafmagnsveita Reykjavíkur and the Establishment of Skýrr}

Rafmagnsveita Reykjavíkur (Reykjavík Electric Company) was founded 1921. In the year 1928, Rafmagnsveita started to use electromechanical accounting machines for accounting and processing accounts receivable and printing invoices. This type of equipment was used for quarter of a century until the advent of unit record equipment.

At this point, the leaders of Rafmagnsveita had been looking for improved ways to process the accounts receivable. In the year 1948 a "Hollerith system", that is unit record equipment based system, was ordered from IBM. At that time imports to Iceland were severely regulated by the government and the permission to import this "expensive" equipment for Rafmagnsveita was not granted. This situation remained unchanged for several years. Hjörleifur Hjörleifsson (1906-1979), a department head and later financial director of Rafmagnsveita, led this effort. He took great interest in automated data processing and he organised the founding of the Icelandic Data Processing Society in the year 1968; he became the first president of the society.

In the year 1950, Dr. Sigurður Sigurðsson (1903-1986) the medical director in Iceland for tuberculosis proposed that Heilsuverndarstöð ríkisins (State Health Institute), Hagstofa Íslands and Rafmagnsveita Reykjavíkur cooperated in establishing a common data processing centre. His proposal was accepted and a joint centre was established that later was named Skýrsluvélar ríkisins og Reykjavíkurbæjar (Skýrr). The government subsequently issued an import permit. Based on the order that Rafmagnsveita had placed with the IBM agent two years earlier, the institution ordered the following equipment: Tabulator IBM 405, Reproducing Punch IBM 513, Collator IBM 077, Sorter IBM 082, Interpreter IBM 552, and more. See Figure 3. The delivery time was two years and IBM delivered the equipment early in the year 1952 [2]. 


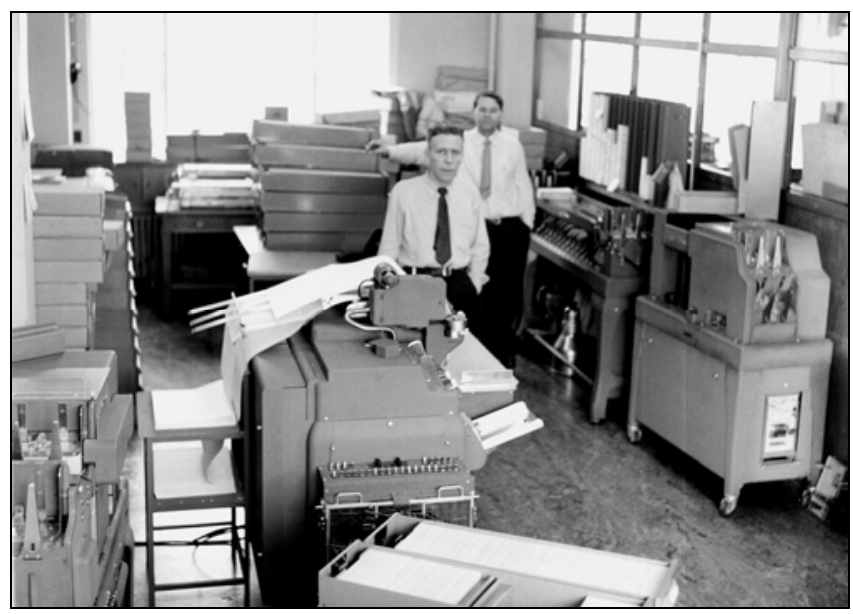

Fig. 3. The machine room of Skýrr at Rafmagnsveita company premises around the year 1955 . Hafsteinn E. Gíslason (1914-1976) in the foreground and Guðmundur Sveinsson in the background.

In the fall of 1951, the preparation work for the unit record processing started at Rafmagnsveita. The customer register had to be punched on cards and the processing organized. An employer at Rafmagnsveita, Guðmundur Sveinsson (1907-2001), organized this work. When the equipment was delivered it was installed in office space at Rafmagnsveita. Some start-up difficulties were experienced but by mid year 1952 the invoices for both electric and hot water usage were sent to every household in Reykjavík - the old accounting machines became obsolete. Skýrr data centre had started operation.

In the beginning, Skýrr worked solely at projects for Rafmagnsveita (70\%) and Hagstofa (30\%). This changed as time passed and in few years Skýrr serviced numerous institutes of the State and City. The hardware was updated accordingly and the staff increased rapidly. See Figure 4.

At Rafmagnsveita the unit record equipment served to process the energy invoices for the City until the year 1964. That year Skýrr obtained the first computer in Iceland of the type IBM 1401.[2, 3] Then the data processing for Rafmagnsveita improved but the data entry and storage media continued to be punched cards and the processing sequential - based on batches of sorted cards. The real changes in processing came in 1968 when Skýrr obtained an IBM 360/30 with magnetic disks and tapes and an IBM 1403 line printer. The main files were now read to tapes or discs and all processing such as sorting and merging of files was greatly facilitated. A primitive version of disc operating system (DOS) controlled the system that made possible batch processing with limited multitasking and parallel processing and print queues.

The data processing at Skýrr grew without bounds in the first decade and faster than any one had foreseen. The space to house the operation had been increased by $500 \%$ by the year 1958 and the tabulators were by that time three with two of the improved type IBM 421. 


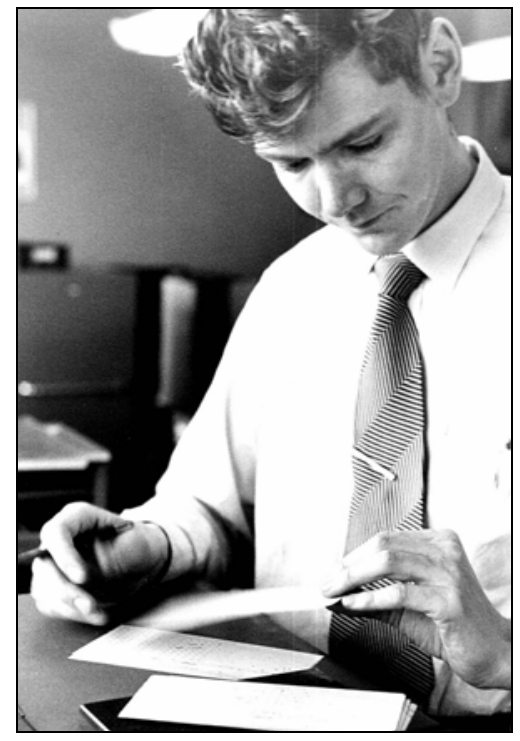

Fig. 4. Eletrographic mark sensing technology was tried out in the first years at Skýrr to mechanise the energy meter readings for electricity and hot water in the homes. The inspectors were to mark the meter readings directly with special pencil on special cards that would subsequently be processed to become punched cards. The process was not reliable and it was discontinued. The author is seen inspecting rejected mark sensed cards in the year 1952.

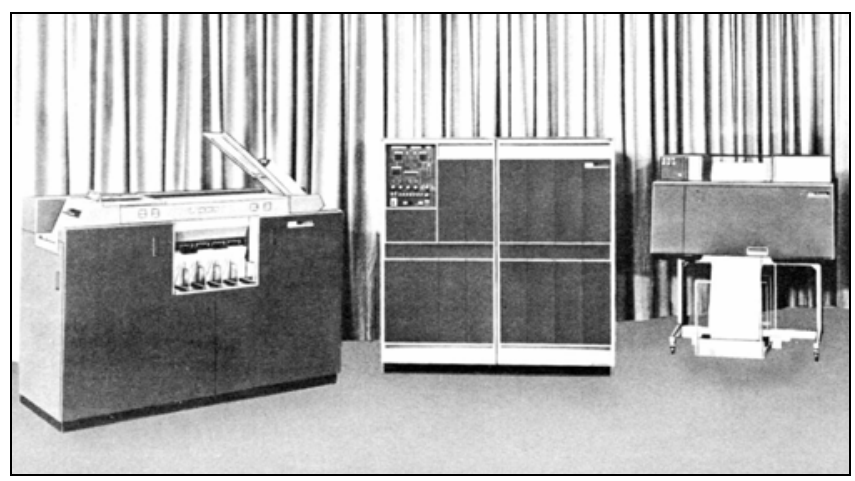

Fig. 5. The IBM 1401 configuration that Skýrr installed in the year 1964 consisting of card reader/punch, the central unit, and a line printer

The use of punched cards dwindled quickly and file processing using punched cards came to an end. The punched cards were still used for a while as data entry media. Soon another innovation came to use - that is entering data on diskettes and later online data entry. The "old fashioned" technology based on punched cards disappeared quickly and by the year 1982, the unit record equipment was completely out of use at Skýrr. In conclusion, we can say that the period of data processing with unit record equipment lasted from the year 1949 to the year 1982. 


\section{References}

[1] Áki Pétursson. IBM-vélar Hagstofunnar. Kafli í Afmælisrit til Porsteins Porsteinssonar á sjötugs afmæli hans 5. apríl 1950 / [nefnd skipuð af stjórn Félags hagfræðinga sá um útgáfuna]. (The IBM equipment at the Statistical Bureau of Iceland. Chapter in Anniversary Edition for Thorsteinn Thorsteinsson on his seventieth years anniversity 5. April 1950. Editor Association of Icelandic Economists, in Icelandic.) Reykjavik, pp. 1-10 (1950)

[2] Kjartansson, Ó.: Upplýsingaiðnaður í hálfa öld. Saga Skýrr 1952-2002 (Fifty years of information technology: The story of Skýrr 1952-2002, in Icelandic) Skýrr, Reykjavík (2002)

[3] Benediktsson, O., Gunnarsson, J., Hreinsson, E.B., Jakobsson, J., Kaldalóns, Ö., Kjartansson, Ó., Rósmundsson, Ó., Sigvaldason, H., Stefánsson, G., Zophoniasson, J.: Computerisation of the Icelandic State and Municipalities: 1964 to 1985. In: Bubenko Jr., J., Impagliazzo, J., Sølvberg, A. (eds.) History of Nordic computing: IFIP WG9.7 first working conference on the history of nordic computing (HiNC1), Trondheim, Norway, June 16-18, 2003. Springer, Heidelberg (2005) 